\title{
EDWARD THOMAS BROWNE
}

I866-I937

Members of the Association, especially those who have served on the Council and many biologists who have worked at the Plymouth Laboratory during the last forty years, will have learned with sorrow and regret of the death of Edward Thomas Browne of "Anglefield", Berkhamsted, on December 10, 1937, in his 72nd year, following a short illness. As a student at Queen's College, Oxford, Browne did not read biology, but after graduation spent some years in London, where he developed an interest in microscopy and the study of freshwater pond life. He became a Fellow of the Royal Microscopical Society in 1884 and a member of the Quekett Club in I887, and was an active worker with both these societies, serving for a time on the council of each and maintaining his interest in them throughout his life.

During the session I89I-92 Browne attended a full course of lectures and practical work in Zoology under Prof. W. F. R. Weldon at University College, London. In the autumn of 1892 he began investigations on coelenterates in the old research laboratory which had been arranged by Ray Lankester on the north side of the gallery surrounding the Zoological Lecture Theatre. In this narrow space tables were provided for six research workers, and it was here that I first met Browne. The rest of the party consisted of $\mathrm{H}$. F. Thompson (now Sir Herbert Thompson), the late Miss Florence Buchanan, then working at marine Polychaetes but who subsequently did Physiological research with Burdon-Sanderson in Oxford, Miss Kircaldy of Oxford and Miss Margaret Robinson, a former Newnham student, who seventeen years later becam: Browne's wife. In addition to Prof. Weldon, who was full of enthusiasm for the Plymouth Laboratory and its work, Dr G. Herbert Fowler, Assistant Professor in the Department, and at the time Secretary of the Marine Biological Association, did much to encourage and help us all and to direct our attention to problems of marine animal life.

In the spring of 1893 Browne spent a month at the Marine Station at Port Erin, in the Isle of Man, and in September paid his first visit to the Plymouth Laboratory. A similar programme was followed in 1894, the intermediate months being spent at University College. In the spring of 1895 he went with W. I. Beaumont and F. W. Gamble to Valencia, on the south-west coast of Ireland, and also spent a month at Plymouth in the summer. In the following year a larger party was organized by him to carry out investigations at Valencia, the additional members being Prof. F. E. Weiss, A. O. Walker and M. D. Hill. The party received much help from the Misses Delap, who had previously taken great interest in the fauna of Valencia Harbour, and from them in later 
years Browne received constant supplies of new material with notes on observations made on the living organisms.

By this time Browne had settled down to specialize on the Medusae and Hydroids, and after the publication of his two papers in the Proceedings of the Zoological Society of London in 1896 and 1897 he was quickly recognized as a leading authority on these coelenterates. For many years he continued to work at University College during the winter half of the year, attending with great regularity from day to day. Already in I896 and I897 he was planning a monograph on the British Medusae, using every endeavour to follow their full life-histories and to connect them with their proper hydroids. As the illustrations to his published papers show he was a skilful artist. Many plates were prepared for use in the proposed monograph, and detailed notes were written. When, two or three years ago, he felt that he would not himself be able to complete the work, he arranged with Mr F. S. Russell to carry on the scheme, paying for a trained biological assistant to help him in the task. He has made provision also for the publication of the monograph when ready under their joint names, so that there is every hope that this part of his life work will not be lost.

In connexion with this work Browne continued to visit different marine laboratories, and made expeditions to places specially suitable for collecting the material he required. His visits to the Plymouth Laboratory as a worker continued from time to time during the next 15 or 20 years, and special mention should be made of the two papers "On keeping medusae alive in an aquarium" (I898) and "A new method for growing hydroids in small aquaria by means of a continuous current tube" (1907). In the first of these he emphasized the advantages of keeping small pelagic marine animals in constant movement by mechanical means in order to keep them healthy in an aquarium. For this purpose he designed an apparatus known as the "plunger-jar", which is still much used at Plymouth, as well as in other biological laboratories. Both this and the "continuous current tube" illustrate one side of his ability, the successful designing and handling of instruments and apparatus for the purposes of his research. His whole technique was excellent and he paid the greatest attention to detail and scientific accuracy. His early experience as a microscopist no doubt served him in good stead in his later work.

Special mention should be made of Browne's work with Rupert Vallentin, which belongs to this period. A series of papers on the Fauna of Falmouth Harbour was published in the Report of the Royal Cornwall Polytechnic Society and in the Fournal of the Royal Institution of Cornwall between I89I and I897 (see I899, p. 69I in list of works below), by Vallentin, which are liable to be lost sight of. Browne visited him and collected with him in Falmouth and they also spent some time together in the Scilly Islands (1904). Vallentin, who had studied Zoology in Munich under Richard Hertwig, visited the Falkland Islands in 1898-99, bringing back a fine collection of Medusae which he handed over to Browne. A preliminary report on these was published in I902, 
and a manuscript with drawings for the full report was prepared but not published. This will probably be revised and arranged for publication by Dr P. L. Kramp of Copenhagen.

On his marriage in December 1909 to Miss M. Robinson, his colleague for many years in the research laboratory at University College, London, he made his home at "Anglefield", Berkhamsted, a house with a good garden on the outskirts of the town. Here he built a special laboratory for his work, and for the housing of his numerous collections and the fine special library on coelenterates which he had got together. Remarkably characteristic was the careful way in which the collections were preserved and arranged, and both these and the scientific pamphlets card-indexed, so that anything could be found at a moment's notice. He had also accumulated a great mass of typewritten notes, all arranged with equal care.

Owing to the reputation he had made as a specialist on the medusae, and the care and accuracy of his work, he at this time received numerous requests to report on collections of medusae from all parts of the world. Although the examination of these collections and the preparation of the reports on them interfered with the progress of the monograph on British medusae, he felt the work well worth undertaking, giving him as it certainly did a broader grasp of the group as a whole, and he hoped that the British monograph would gain greatly in the end by the delay. When therefore he was settled in his own laboratory at "Anglefield", he worked chiefly on foreign collections, and the reports he published, all of which are illustrated by his own beautiful and accurate figures, show that he put much time and effort into making them as perfect as the specimens allowed.

He was fortunate when he first went to Berkhamsted in having as a near neighbour the Rev. Canon A. M. Norman, in whom he found a marine naturalist after his own heart. The two became very close friends, for in addition to this bond, Browne and Norman were both keen gardeners and both found the care of their gardens a relief from the.close work of systematic zoology. Norman's death was a great grief to Browne.

He became a Fellow of the Zoological Society in 1894, and when he was at University College he paid frequent visits to the Zoological Gardens. Among his other activities he was a good photographer and spent much time and effort in getting fine pictures of many of the animals in the Gardens in characteristic attitudes, and especially the birds.

After his marriage and settlement at "Anglefield", Browne, who was a good business man, took a special interest in the administration of several of the scientific societies of which he was a member. He was elected a Fellow of the Linnean Society in I913 and served on the Council from 1915 to 1923 , being a Vice-President from 1920 to 1923 . He took great interest in the work of the Council, and was especially active as a member of the Library Committee.

He was also a member of the Challenger Society for the Promotion of Oceanography and a regular attendant at its meetings. 
But I think we can claim that he gave his most active support to the Marine Biological Association and its Plymouth Laboratory. He became a member of the Association in 1893 , the year in which he first visited the Laboratory, and from 1895 onwards he was always active and helpful in advising on business and administrative matters. He served as an ordinary member of Council from 1913 until 1919, in which year he supported his friend Dr G. P. Bidder, who was collecting a fund for the enlargement of the Laboratory buildings, by giving a donation of $£ 500$ which made the proposed scheme possible. By this donation he became a Life-Governor with a permanent seat on the Council of the Association. He gave substantial financial help to all subsequent efforts for the enlargement of the Laboratory and the extension of its work, spending also much time and thought on the various plans proposed. In all such matters his advice and business experience contributed greatly to the progress of the Association's work. His special donations made during his lifetime amounted to $£ 2655$, and in addition he provided funds to enable young naturalists to carry out particular lines of work in the Laboratory. Substantial sums have also been left to the Association in his will to enable these activities to continue.

Browne was a real "naturalist", in the old sense in which that word was understood, who, as a result of an academic training, early took a useful part in the transition that led to the "ecologists" of to-day. His interest was primarily in living animals and plants in their natural surroundings and for him work in the laboratory was undertaken as an aid to elucidating the relationships of the organism to the physical and biological conditions in which it lived. His interests were not confined to his hydroids and medusae, but extended to all the animals of the sea and equally to the birds and plants of the countryside and the garden.

As a man he was generous and good-hearted, the staunch friend of a large and varied group of biologists, whom he was always anxious to help in any way he could in their scientific work. His knowledge and experience were freely given to them all and especially he found great pleasure in helping those just entering on biological research. But it was not until one had the happiness to know him in his own charming home, with a wife who sympathized so fully with all his pursuits, that the full measure of his kindness was made plain.

E. J. ALLEN. 


\section{LIST OF PAPERS BY E. T. BROWNE}

1895. Report on the medusae of the L.M.B.C. District. Trans. Lpool Biol. Soc., Vol. Ix, pp. 243-86.

On the variation of the tentaculocysts of Aurelia aurita. Quart. Fourn. Micr. Sci., Vol. xxxvII, pp. 245-5I.

On the variation of Haliclystus octoradiatus. Quart. Fourn. Micr. Sci., Vol. xxxvili, pp. I-8.

1896. On British hydroids and medusae. Proc. Zool. Soc. London, pp. 459500.

- - On the changes in the pelagic fauna of Plymouth during September, I893 and I895. Fourn. Mar. Biol. Assoc., Vol. IV, pp. I68-73.

- The medusae of Valencia Harbour, County Kerry. Irish Naturalist, July, pp. I79-8I.

1897. On Tubularia crocea in Plymouth Sound. Fourn. Mar. Biol. Assoc., Vol. v, pp. 54-5.

The hydroids of Valencia Harbour, Ireland. Irish Naturalist, pp. 241-6. On British medusae. Proc. Zool. Soc. London, pp. 816-35.

Revised list of hydromedusae of L.M.B.C. District. Trans. Lpool Biol. Soc., Vol. XI, pp. 147-50.

1898. On keeping medusae alive in an aquarium. Fourn. Mar. Biol. Assoc., Vol. v, pp. 176-80.

On the pelagic fauna of Plymouth for September, i897. Fourn. Mar. Biol. Assoc., Vol. v, pp. 186-92.

1899. (With Beaumont, W. I. and Gamble, F. W.) The fauna and flora of Valencia Harbour on the west coast of Ireland. I. The pelagic fauna (1895-98). II. The medusae (1895-98). Proc. R. Irish Acad., Ser. 3, Vol. v, pp. 667-93, 694-736.

1901. Variation in Aurelia aurita. Fourn. Biometrika, Vol. I, pp. 90-108.

1902. A preliminary report on hydromedusae from the Falkland Islands. Ann. Mag. Nat. Hist., Ser. 7, Vol. Ix, pp. 272-84.

1903. Report on some medusae from Norway and Spitzbergen. Bergens Mus. Aårbog, No. 4, pp. I-36.

1904. (With Vallentin, R.) On the marine fauna of the Isles of Scilly. Fourn. Roy. Inst. Cornwall, Vol. L, pp. 120-32.

Hydromedusae, with a revision of the Williadae and Petasidae. Faun. Geogr. Maldive Laccadive Archip., Vol. II, pp. 722-49.

Scyphomedusae. Faun. Geogr. Maldive Laccadive Archip., Vol. II, Supp. pp. 958-72.

1905. A report on the medusae found in the Firth of Clyde (I9OI-2). Proc. Roy. Soc. Edin., Vol. xxv, pp. 738-78.

Notes on the pelagic fauna of the Firth of Clyde (I90I-2). Proc. Roy. Soc. Edin., Vol. xxv, pp. 779-91. 
I905 Report on the medusae (Hydromedusae, Scyphomedusae, Ctenophora) collected by Professor Herdman at Ceylon, in 1902. Report on the Pearl Oyster Fisheries of the Gulf of Manaar Royal Soc. Suppl. Rep., Vol. xxvII, pp. I3I-66.

1906. On the fresh-water medusa Limnocnida tanganicae and its occurrence in the River Niger. Ann. Mag. Nat. Hist., Ser. 7, Vol. xvir, pp. 305-6. On the fresh-water medusa liberated by Microhydra ryderi, Potts, and a comparison with Limnocodium. Quart. Fourn. Micr. Sci., Vol. L, pp. $635-45$.

- Biscayan plankton collected during a cruise of H.M.S. Research 1900. Pt Ix. The medusae. Trans. Linn. Soc., 2nd Ser. Zool., Vol. x, pp. I63-I87.

1907. A new method for growing hydroids in small aquaria by means of a continuous current tube. Fourn. Mar. Biol. Assoc., Vol. viII, pp. $37-43$.

The hydroids collected by the Huxley from the north side of the Bay of Biscay in August, 1906. Fourn. Mar. Biol. Assoc., Vol. viII, pp. 15-36. A revision of the medusae belonging to the family Laodiceidae. Ann. Mag. Nat. Hist., Ser. 7, Vol. xx, pp. 457-80.

1908. The medusae of the Scottish National Antarctic Expedition. Trans. Roy. Soc. Edin., Vol. XLVI, pp. 233-5I.

On the fresh-water medusa, Limnocnida tanganicae, discovered in the River Niger by the late J. S. Budgett. Budgett Memorial Volume, pp. $47 \mathrm{I}-80$.

1910. Coelenterata. V. Medusae. Nat. Antarct. Exped,, Nat. Hist., Vol. v, pp. I-62.

I912. "The floating animals" and "Preservation of marine organisms." (With G. H. Fowler and E. J. Allen.) Science of the Sea. Prepared by the Challenger Society and edited by G. Herbert Fowler. London, Murray. I9I2. Chapters v and XI, pp. I62-99 and 344-82. Second edition (revised). Oxford: Clarendon Press. 1928. pp. 206-40 and 386-425.

19I6. Medusae from the Indian Ocean. (Collected by Prof. Stanley Gardiner in H.M.S. Sealark, in I905.) Trans. Linn. Soc., and Ser. Zool., Vol. XVII, pp. I69-2 Io.

- Notes on some jelly-fishes from Okhamandal in Kattiawar collected by Mr James Hornell in, 1904-5. Rep. Govt. Baroda on Mar. Zool. Okhamandal in Kattiawar, Pt. II, pp. I $5 \mathrm{I}-5$.

1919-20. Ernst Heinrich Philipp August Haeckel. Proc. Linn. Soc., Sess. 132, pp. 39-43.

1926. Siphonophorae from the Indian Ocean collected by Prof. Stanley Gardiner in H.M.S. Sealark. Trans. Linn. Soc., 2nd Ser. Zool., Vol. xIx, pp. 55-86.

- Report on the medusae, Cambridge Expedition to the Suez Canal. Trans. Zool. Soc., London, Vol. XxIr, pp. IOS-I5. 